\title{
Hubungan kemampuan numerik dan kemampuan spasial terhadap kemampuan komuni- kasi matematis siswa
}

\author{
Bedilius Gunur ${ }^{1^{*}(D)}$, Derfina Agustavira Lanur ${ }^{1}$, Polikarpus Raga ${ }^{1}$ \\ ${ }^{1}$ Program Studi Pendidikan Matematika, Universitas Katolik Indonesia Santu Paulus Ruteng, Indonesia \\ * Corresponding Author. E-mail: gbedilius@gmail.com
}

\begin{tabular}{|c|c|}
\hline ARTICLE INFO & ABSTRACT \\
\hline $\begin{array}{l}\text { Keywords: } \\
\text { Kemampuan numerik, } \\
\text { Kemampuan spasial, } \\
\text { Komunikasi matematis, } \\
\text { Numeric ability, } \\
\text { Spatial ability, } \\
\text { Mathematical communi- } \\
\text { cation. }\end{array}$ & $\begin{array}{l}\text { Penelitian ini bertujuan untuk mendeskripsikan (1) hubungan parsial antara kemampuan } \\
\text { numerik dan kemampuan spasial dengan kemampuan komunikasi matematis siswa; (2) hu- } \\
\text { bungan kemampuan numerik dan kemampuan spasial secara simultan terhadap kemampuan } \\
\text { komunikasi matematis siswa. Penelitian ini merupakan penelitian korelasional dengan populasi } \\
\text { adalah siswa kelas VII SMPK Santu Fransiskus Xaverius Ruteng yang terletak di Kecamatan } \\
\text { Langke Rembong Kabupaten Manggarai, Provinsi Nusa Tenggara Timur. Sampel sebanyak } 66 \\
\text { siswa dipilih menggunakan teknik random sampling. Data diperoleh dari tes kemampuan } \\
\text { numerik, tes kemampuan spasial, dan tes kemampuan komunikasi matematis. Analisis uji pra- } \\
\text { syarat menggunakan uji normalitas, uji linearitas, dan uji multikolinearitas. Analisis data meng- } \\
\text { gunakan analisis korelasi sederhana dan korelasi ganda. Hasil penelitian menunjukkan bahwa } \\
\text { (1) terdapat hubungan signifikan antara kemampuan numerik dengan kemampuan komuni- } \\
\text { kasi matematis siswa dengan koefisien korelasi } 0,457 \text { dan besar sumbangan kemampuan } \\
\text { numerik terhadap kemampuan komunikasi matematis sebesar } 20,9 \% \text {; (2) terdapat hubungan } \\
\text { signifikan antara kemampuan spasial dengan kemampuan komunikasi matematis siswa } \\
\text { dengan koefisien korelasi } 0,426 \text { dan besar sumbangan kemampuan spasial terhadap kemam- } \\
\text { puan komunikasi matematis sebesar } 18,1 \% \text {; (3) terdapat hubungan signifikan kemampuan } \\
\text { numerik dan kemampuan spasial secara simultan terhadap kemampuan komunikasi mate- } \\
\text { matis siswa dengan koefisien korelasi 0,555 dengan kontribusi kedua variabel secara simultan } \\
\text { terhadap kemampuan komunikasi matematis siswa sebesar 30,8\%. }\end{array}$ \\
\hline
\end{tabular}

This study aimed to describe (1) a partial relationship between students' numerical abilities and spatial abilities with mathematical communication abilities; (2) simultaneous relationship between students' numerical and spatial abilities to mathematical communication abilities. This study used correlational research. The population of this research was seventh-grade students of SMPK St. Fransiskus Xaverius Ruteng, located in Langke Rembong Subdistrict, Manggarai Regency, East Nusa Tenggara, Indonesia. A sample of 66 students was selected using the random sampling technique. Data were obtained by using numerical ability tests, spatial ability tests, and mathematical communication ability test. Before analyzing the data, a normality test, linearity test, and multicollinearity test were carried out. The data were analyzed by using a simple correlation and multiple correlations. Data analysis showed that (1) there was a significant relationship between students' numerical abilities and mathematical communication abilities with correlation coefficient 0,457 and the contribution of numerical ability to mathematical communication ability was 20.9\%; (2) there was a significant relationship between students' spatial abilities and mathematical communication abilities with correlation coefficient 0,426 and the contribution of spatial ability to mathematical communication ability is $18.1 \%$; (3) there was a simultaneous relationship between students' numerical and spatial abilities to students mathematical communication abilities with correlation coefficient 0,555 with the contribution of both variables to students' mathematical communication ability was $30.8 \%$.

\section{SCAN ME}

\section{How to Cite:}

Gunur, B., Lanur, D. A., \& Raga, P. (2019). Hubungan kemampuan numerik dan kemampuan spasial terhadap kemampuan komunikasi matematis siswa. PYTHAGORAS: Jurnal Pendidikan Matematika, 14(2), 224-232. doi: https://doi.org/10.21831/pg.v14i2.27250 


\section{PENDAHULUAN}

Dalam mempelajari matematika pada setiap jenjang pendidikan, siswa dituntut untuk mencapai kompetensi yang telah ditetapkan (Abed, Al-Absi, \& Abu shindi, 2015; Trafton \& Midgett, 2000). Salah satu kompetensi yang diharapkan dapat dicapai oleh siswa adalah kemampuan komunikasi matematis, tidak terkecuali untuk siswa di Indonesia. Dalam Permendikbud RI Nomor 21 Tahun 2016 tentang standar isi pendidikan dasar dan menengah (Kemendikbud, 2018), disebutkan bahwa salah satu kompetensi yang harus dikuasai yaitu siswa memiliki kemampuan mengkomunikasikan gagasan matematika dengan jelas dan efektif. Hal tersebut mencerminkan bahwa arah atau orientasi pembelajaran matematika di Indonesia salah satunya adalah komunikasi matematika. Dalam proses pembelajaran sendiri, kemampuan komunikasi siswa dapat diketahui dari kemampuan siswa dalam mendiskusikan masalah dan membuat ekspresi matematika secara tertulis baik berupa gambar, model matematika, maupun simbol atau bahasanya sendiri.

Komunikasi adalah suatu bagian esensial dari matematika dan pendidikan matematika karena berkomunikasi di dalam mata pelajaran matematika membuat siswa dapat berpikir dan bernalar tentang matematika (Fatmasuci, 2017; Habsah, 2017). Selain itu, komunikasi merupakan sarana pokok dalam mengekspresikan ide atau hasil pemikirannya baik secara lisan maupun tertulis (NCTM, 2000). Pendapat tersebut mengisyaratkan pentingnya komunikasi dalam pembelajaran matematika, karena melalui komunikasi siswa dapat menyampaikan ide-idenya kepada guru maupun kepada siswa lainnya. Selain itu, komunikasi juga diperlukan untuk melengkapi setiap proses matematis yang lain, karena tanpa memiliki komunikasi matematis, siswa akan sulit untuk memecahkan masalah matematika (Hartati, Abdullah, \& Haji, 2017; Junita, 2016; Sukoco \& Mahmudi, 2016).

Faktanya, kemampuan komunikasi matematis siswa Indonesia masih tergolong rendah. Hal ini salah satunya dapat dilihat dari hasil laporan Trends in International Mathematics and Science Study (TIMSS) tahun 2011 yang memperlihatkan bahwa siswa Indonesia lemah dalam mengerjakan soal-soal yang menuntut berargumentasi dan berkomunikasi (Delyana, 2014). Beberapa penelitian terdahulu (misalnya Whardani, 2016; Wijayanto, Fajriah, \& Anita, 2018) melaporkan bahwa kemampuan komunikasi matematika siswa masih tergolong rendah. Rendahnya kemampuan komunikasi matematis siswa juga terjadi di SMPK Santu Fransiskus Xaverius Ruteng. Dari hasil wawancara tidak terstruktur dengan guru matematika SMPK Santu Fransiskus Xaverius Ruteng, diketahui bahwa mayoritas siswa masih mengalami kesulitan menyatakan masalah menggunakan gambar dan sulit menjelaskan ide dengan menggunakan bahasa maupun simbol-simbol matematika. Kesulitan-kesulitan yang dialami siswa berdasarkan hasil wawancara tersebut mengindikasikan kurangnya kemampuan komunikasi matematis siswa.

Rendahnya kemampuan komunikasi matematis siswa dapat disebabkan oleh banyak faktor, di antaranya faktor eksternal dan internal. Faktor eksternal meliputi sarana dan prasarana, kurikulum serta lingkungan. Sedangkan faktor internal meliputi bakat, motivasi, kemampuan kognitif/akademik, minat, serta fisik dan psikis siswa. Fokus dalam tulisan ini adalah faktor internal, yaitu kemampuan akademik siswa. Salah satu jenis kemampuan akademik yang diduga mempunyai peranan terhadap kemampuan komunikasi matematis siswa adalah kemampuan numerik (matematis-logis). Menurut (Abed et al., 2015) kemampuan numerik merupakan kemampuan yang berkaitan dengan kecermatan dan kecepatan dalam penggunaan fungsi-fungsi hitung. Irawan (2016); Irawan dan Kencanawaty (2017) menjelaskan bahwa kemampuan numerik adalah kemampuan seseorang dalam melakukan perhitungan dengan angka-angka. Sedangkan Gunur, Makur, dan Ramda (2018) mengatakan bahwa kemampuan numerik merupakan dasar dalam belajar matematika, khususnya yang berhubungan dengan operasi hitung bilangan.

Siswa akan mengalami kesulitan dalam belajar matematika apabila tidak mempunyai kemampuan numerik yang mencukupi (Achdiyat \& Utomo, 2018). Jayantika, Ardana, \& Sudiarta (2013) juga mengatakan bahwa seseorang dengan kemampuan numerik yang baik mampu mengelola logika dan melibatkan proses berpikir logis, berhitung, menyusun pola hubungan, serta memecahkan masalah. Dengan demikian, agar siswa berprestasi dengan baik dalam tes kecakapan umum, mereka harus memiliki kemampuan numerik yang tinggi (Badru, 2016). Beberapa penelitian terdahulu seperti Kusuma dan Budiyono (2014); Suparlan dan Juhariah (2009); Wibowo (2016) melaporkan bahwa terdapat hubungan yang positif dan signifikan antara kemampuan numerik dengan prestasi belajar matematika; semakin baik kemampuan numerik siswa maka prestasi belajar matematika juga baik. Selain itu, penelitian Irawan dan Kencanawaty (2017) juga menunjukkan bahwa kemampuan numerik juga berpengaruh dalam meningkatkan kemampuan berpikir kritis siswa. 
Selain kemampuan numerik, salah satu faktor lain yang diduga berpengaruh dalam peningkatan kemampuan komunikasi matematis siswa yaitu kemampuan spasial (keruangan-visual). Carter (2005); Tambunan (2006) menjelaskan bahwa kemampuan spasial adalah kemampuan untuk memahami bentuk geometris, dan kemampuan memahami serta mengidentifikasi pola dan artinya. Menurut Achdiyat dan Utomo (2018) kemampuan spasial akan menunjukkan kemampuan siswa dalam memahami perspektif ruang dan dimensi. Kemampuan spasial didefinisikan sebagai kapasitas seseorang untuk mengenali dan melakukan penggambaran atas objek/pola yang diterima otak (Jayantika et al., 2013). Selain itu, Achdiyat dan Utomo (2018) menjelaskan bahwa dalam kemampuan spasial diperlukan adanya pemahaman kiri kanan, pemahaman perspektif, bentuk-bentuk geometris, menghubungkan konsep spasial dengan angka, dan kemampuan dalam transformasi mental dari bayangan visual. Pemahamanpemahaman tersebut sangat diperlukan dalam mempelajari matematika. Adanya konseptualisasi spasial yang baik merupakan aset untuk memahami konsep-konsep matematika. Kemahiran siswa dalam bidang spasial tentu akan memudahkan baginya dalam menyelesaikan masalah matematis terutama dalam menyatakan masalah menggunakan gambar dan sulit menjelaskan ide dengan menggunakan bahasa maupun simbol-simbol matematika. Karena itu, dapat dikatakan bahwa kemahiran siswa dalam bidang spasial akan berdampak terhadap kemampuan komunikasi yang baik pula.

Beberapa penelitian terdahulu (misalnya Jayantika et al., 2013; Harmony \& Theis, 2012; Tambunan, 2006) melaporkan bahwa terdapat hubungan yang positif antara kemampuan spasial dengan prestasi belajar matematika, dimana untuk meningkatkan prestasi belajar matematika siswa dapat dilakukan dengan meningkatkan kemampuan spasial siswa. Dengan demikian, kemampuan spasial yang berkembang dengan baik dalam diri siswa mampu membantu siswa dalam menyelesaikan soal-soal yang berkaitan dengan menciptakan imajinasi bentuk dalam pikirannya maupun dalam wujud benda-benda tiga dimensi, atau membayangkan posisi suatu obyek geometri setelah obyek tersebut mengalami perputaran dan pencerminan serta menduga secara akurat bentuk sebenarnya dari bangun ruang geometri yang dipandang dari sudut pandang tertentu.

Berdasarkan uraian latar belakang masalah dan kajian teori yang telah dikemukakan sebelumnya, dapat dipahami bahwa komunikasi matematis merupakan salah aspek penting dalam pembelajaran matematika. Kemampuan komunikasi matematis siswa diduga kuat dipengaruhi oleh banyak faktor di antaranya yaitu kemampuan numerik dan kemampuan spasial siswa itu sendiri. Untuk menguji dugaan tersebut, maka penelitian bertujuan untuk mendeskripsikan (1) hubungan antara kemampuan numerik dan kemampuan komunikasi matematis siswa; (2) hubungan antara kemampuan spasial dan kemampuan komunikasi matematis siswa; dan (3) hubungan kemampuan numerik dan kemampuan spasial secara simultan terhadap kemampuan komunikasi matematis siswa.

\section{METODE}

Penelitian ini merupakan penelitian korelasional ex post facto. Populasi dalam penelitian ini adalah siswa kelas VII SMPK Santu Fransiskus Xaverius Ruteng, Nusa Tenggara Timur yang tersebar dalam enam kelas. Banyaknya sampel ditetapkan menggunakan rumus Yamane (1967) dengan tingkat presisi yang ditetapkan sebesar 5\%, sehingga diperoleh ukuran sampel yaitu 66 siswa. Peneliti menggunakan teknik simple random sampling untuk memperoleh unit sampel dari setiap kelas. Instrumen yang digunakan untuk pengumpulan data adalah tes kemampuan numerik, tes kemampuan spasial, dan tes kemampuan komunikasi matematis siswa. Instrumen tes untuk mengukur kemampuan numerik dan kemampuan spasial merupakan soal pilihan ganda dengan jumlah butir soal berturut-turut 20 butir dan 30 butir. Sedangkan instrumen tes untuk mengukur kemampuan komunikasi matematis siswa merupakan soal uraian sebanyak 5 butir. Ketiga instrumen tersebut disusun berdasarkan indikator kemampuan numerik, indikator kemampuan spasial, dan indikator kemampuan komunikasi matematis siswa.

Sebelum digunakan, ketiga instrumen tersebut divalidasi dan diestimasi reliabilitasnya. Estimasi reliabilitas instrumen menggunakan rumus Kuder Richardson-20 untuk tes pilihan ganda, dan Cronbach's Alpha untuk tes uraian. Dari hasil estimasi reliabilitas tes kemampuan numerik, diperoleh koefisien reliabilitas sebesar 0,83 sehingga instrumen tes ini dikategorikan memiliki reliabilitas tinggi. Dari hasil estimasi reliabilitas tes kemampuan spasial, diperoleh koefisien reliabilitas sebesar 0,86 sehingga instrumen tes ini dikategorikan memiliki reliabilitas tinggi. Sementara itu, hasil estimasi reliabilitas tes kemampuan komunikasi matematis memperoleh koefisien reliabilitas sebesar 0,61 sehingga tes ini dikategorikan memiliki reliabilitas tinggi.

Data hasil penelitian selanjutnya dianalisis menggunakan analisis korelasi sederhana dan analisis korelasi ganda. Analisis korelasi sederhana digunakan untuk menguji hipotesis yang hanya melibatkan satu variabel bebas 
dan satu variabel terikat, yaitu melihat hubungan antara kemampuan numerik dengan kemampuan komunikasi matematis siswa dan hubungan antara kemampuan spasial dengan kemampuan komunikasi matematis siswa. Sedangkan analisis korelasi ganda digunakan untuk menguji hipotesis yang melibatkan dua variabel bebas dan satu variabel terikat, yaitu hubungan yang simultan antara kemampuan numerik dan kemampuan spasial terhadap kemampuan komunikasi matematis siswa. Sedangkan untuk mengetahui besarnya kontribusi kemampuan numerik dan kemampuan spasial secara simultan terhadap kemampuan komunikasi matematis siswa digunakan rumus koefisien determinasi $\left(r^{2}\right)$. Besar $r^{2}$ dinyatakan dengan persen yang menunjukkan besarnya kontribusi variabel bebas terhadap variabel terikat. Selanjutnya, dilakukan uji $t$ untuk menguji ada atau tidaknya hubungan yang signifikan antara kemampuan numerik, kemampuan spasial, dan kemampuan komunikasi matematis siswa. Analisis data dilakukan pada taraf signifikan $95 \%(\alpha=0,05)$.

\section{HASIL DAN PEMBAHASAN}

Pengujian prasyarat analisis dengan statistik korelasi mensyaratkan data yang dianalisis berasal dari populasi berdistribusi normal, berpola linear, dan tidak berhubungan multikolinear (tiga variabel). Untuk itu, dilakukan uji normalitas, uji linearitas, dan uji multikolinearitas. Uji normalitas dilakukan untuk mengetahui apakah sampel yang diteliti berasal dari populasi yang berdistribusi normal atau tidak. Uji normalitas dilakukan terhadap data kemampuan numerik, data kemampuan spasial, dan data kemampuan komunikasi matematis siswa pada taraf signifikansi 0,05 dan hasilnya disajikan pada Tabel 1 .

Tabel 1. Hasil Uji Normalitas

\begin{tabular}{lcc}
\hline Data Sampel & $\begin{array}{c}\text { Kolmogorov- } \\
\text { Smirnov }\end{array}$ & Kesimpulan \\
\hline Kemampuan Numerik & 0,341 & Normal \\
Kemampuan Spasial & 0,445 & Normal \\
Komunikasi Matematis & 0,494 & Normal \\
\hline
\end{tabular}

Tabel 1 menunjukkan bahwa baik data kemampuan numerik, data kemampuan spasial maupun data kemampuan komunikasi diperoleh nilai Kolmogorov-Smirnov jauh lebih besar dari nilai signifikansi yang ditetapkan $(\alpha=0,05)$, hal ini berarti sampel yang diambil berasal dari populasi berdistribusi normal.

Selanjutnya dilakukan uji linearitas yang bertujuan untuk mengetahui apakah bentuk/model regresi $X$ terhadap $Y$ linear atau tidak. Uji linearitas dilakukan terhadap data kemampuan numerik dengan data kemampuan komunikasi matematis siswa, juga terhadap data kemampuan spasial dengan data kemampuan komunikasi matematis siswa pada taraf signifikansi 0,05. Hasil uji linearitas sebaran data disajikan pada Tabel 2.

Tabel 2. Hasil Uji Linearitas Sebaran Data

\begin{tabular}{lccl}
\hline Variabel Independen & $F$ & Nilai Sig. & Keterangan \\
\hline $\begin{array}{l}\text { Kemampuan Numerik*Kemampuan } \\
\text { Komunikasi matematis }\end{array}$ & 1,123 & 0,360 & Hubungan Linear \\
$\begin{array}{l}\text { Kemampuan Spasial*Kemampuan } \\
\text { Komunikasi matematis }\end{array}$ & 0,619 & 0,776 & Hubungan Linear \\
\hline
\end{tabular}

Berdasarkan Tabel 2 diketahui bahwa harga $F$ untuk deviation from Linearity kemampuan numerik terhadap kemampuan komunikasi matematis diperoleh nilai sebesar 1,123 dengan nilai signifikansi 0,360, dengan demikian hubungan kemampuan numerik terhadap kemampuan komunikasi matematis linear. Selanjutnya, harga $F$ untuk deviation from Linearity kemampuan spasial terhadap kemampuan komunikasi matematis diperoleh nilai sebesar 0,619 dengan nilai signifikansi 0,776 , sehingga hubungan kemampuan spasial terhadap kemampuan komunikasi matematis linear.

Uji multikolinearitas dimaksudkan untuk mengetahui apakah terdapat hubungan yang cukup kuat antar variabel bebas. Jika terdapat hubungan yang tinggi, berarti ada aspek yang sama yang diukur pada variabel bebas. Hal ini tidak layak digunakan untuk menentukan hubungan secara bersama-sama variabel bebas terhadap variabel terikat. Uji multikolinearitas dalam penelitian ini dilakukan terhadap data kemampuan numerik dan data kemampuan spasial menggunakan nilai Variance Inflation Factor (VIF) dan tolerance, dengan kriteria jika nilai VIF kurang 
dari 10 dan tolerance mendekati 1, maka dapat disimpulkan data tidak multikolinear. Hasil uji multikolinearitas variabel bebas disajikan pada Tabel 3 .

Tabel 3. Hasil Uji Multikolinearitas

\begin{tabular}{lccc}
\hline \multirow{2}{*}{ Model } & \multirow{2}{*}{ Sig. } & \multicolumn{2}{c}{ Collinearity Statistics } \\
\cline { 3 - 4 } & & Tolerance & VIF \\
\hline Kemampuan Numerik & 0,001 & 0,937 & 1,067 \\
Kemampuan Spasial & 0,003 & 0,937 & 1,067 \\
\hline
\end{tabular}

Tabel 3 menunjukkan bahwa nilai VIF untuk kedua variabel kemampuan numerik dan kemampuan spasial kurang dari 10 dengan nilai tolerance mendekati 1 . Dengan demikian, dapat disimpulkan bahwa dalam korelasi antara variabel bebas kemampuan numerik $\left(X_{1}\right)$, dan kemampuan spasial $\left(X_{2}\right)$, dengan variabel terikat kemampuan komunikasi matematis siswa $(Y)$, tidak terjadi hubungan yang multikolinear antar variabel bebas. Hal ini menunjukkan bahwa dapat ditentukan hubungan kedua variabel bebas kemampuan komunikasi matematis secara simultan. Setelah data yang diperoleh berdistribusi normal, berpola linier, dan tidak terjadi masalah multikolinearitas maka dilanjutkan dengan uji hipotesis.

Tabel 4. Hasil Uji Hipotesis

\begin{tabular}{lccccc}
\hline Variabel & $\begin{array}{c}\text { Nilai Koefisien } \\
\text { Korelasi }\left(r_{x y}\right)\end{array}$ & Sig. & $t_{\text {hitung }}$ & $t_{\text {tabel }}$ & $r^{2}(\%)$ \\
\hline $\begin{array}{l}\text { Kemampuan Numerik }\left(X_{1}\right) \text { dan Kemampuan Komunikasi } \\
\quad \text { Matematis }(Y)\end{array}$ & 0,457 & 0,000 & 4,111 & 1,998 & 20,9 \\
$\begin{array}{l}\text { Kemampuan Spasial }\left(X_{2}\right) \text { dan Kemampuan Komunikasi } \\
\quad \text { Matematis }(Y)\end{array}$ & 0,426 & 0,000 & 3,767 & 1,998 & 18,1 \\
$\begin{array}{l}\text { Kemampuan Numerik }\left(X_{1}\right) \text {, Kemampuan Spasial }\left(X_{2}\right) \text { dan } \\
\text { Kemampuan Komunikasi Matematis }(Y)\end{array}$ & 0,555 & 0,000 & 5,337 & 1,998 & 30,8 \\
\hline
\end{tabular}

Tabel 4 menyajikan hasil analisis korelasi antara variabel bebas dan variabel terikat. Hasil perhitungan nilai koefisien korelasi antara kemampuan numerik dengan kemampuan komunikasi matematis siswa adalah 0,457 dengan nilai signifikansi 0,000 dan nilai $t_{\text {nitung }}=4,111$ lebih dari $t_{\text {tabel }}=1,998$. Hal ini berarti terdapat hubungan yang signifikan antara kemampuan numerik dengan kemampuan komunikasi matematis siswa kelas VII SMPK Santu Fransiskus Xaverius Ruteng, dengan besarnya kontribusi kemampuan numerik terhadap kemampuan komunikasi matematis adalah 20,9\%. Kemudian, hasil perhitungan nilai koefisien korelasi antara kemampuan spasial dengan kemampuan komunikasi matematis siswa adalah 0,426 dengan nilai signifikansi 0,000 dan nilai $t_{\text {hitung }}=3,767$ lebih dari $t_{\text {tabel }}=1,998$. Hal ini berarti terdapat hubungan yang signifikan antara kemampuan spasial dengan kemampuan komunikasi matematis siswa kelas VII SMPK Santu Fransiskus Xaverius Ruteng, dengan besarnya kontribusi kemampuan spasial terhadap kemampuan komunikasi matematis adalah 18,1\%. Selanjutnya, hasil perhitungan nilai koefisien korelasi antara kemampuan numerik dan kemampuan spasial secara simultan terhadap kemampuan komunikasi matematis siswa adalah 0,555 dengan nilai signifikansi 0,000 dan nilai $t_{\text {hitung }}=5,337$ lebih dari $t_{\text {tabel }}$ $=1,998$. Hal tersebut menunjukkan bahwa terdapat hubungan signifikan antara kemampuan numerik dan kemampuan spasial secara simultan terhadap kemampuan komunikasi matematis siswa kelas VII SMPK Santu Fransiskus Xaverius Ruteng, dengan besarnya kontribusi kemampuan numerik dan kemampuan spasial secara simultan terhadap kemampuan komunikasi matematis adalah $30,8 \%$, sedangkan sisanya sebesar $69,2 \%$ dipengaruhi oleh faktor lain yang tidak diteliti.

\section{Pembahasan}

Hasil penelitian ini menunjukkan bahwa kemampuan numerik memiliki hubungan yang signifikan dengan kemampuan komunikasi matematis siswa kelas VII SMPK Santu Fransiskus Xaverius Ruteng, dengan tingkat hubungan dari kedua variabel tersebut cukup kuat. Beberapa penelitian terdahulu yang mengkaji tentang hubungan kemampuan numerik (misalnya Irawan dan Kencanawaty, 2017; Gunur et al., 2018) menunjukkan bahwa kemampuan numerik memiliki hubungan dengan kemampuan matematis lainnya, termasuk kemampuan berpikir kritis dan kemampuan pemecahan masalah. Walaupun kedua peneliti tersebut mengkaji pada aspek kemampuan 
matematis lainnya, tetapi kedua hasil penelitian tersebut menunjukkan bagaimana peran dan kontribusi kemampuan numerik terhadap keberhasilan belajar siswa yang mana salah satunya adalah kemampuan komunikasi. Temuan penelitian juga menunjukkan bahwa kemampuan spasial memiliki hubungan yang signifikan dengan kemampuan komunikasi matematis siswa kelas VII SMPK Santu Fransiskus Xaverius Ruteng, dengan tingkat hubungan dari kedua variabel tersebut cukup kuat. Hasil penelitian ini sejalan dengan hasil penelitian yang dilakukan oleh Achdiyat dan Utomo (2018) yang menjelaskan bahwa kemampuan spasial memiliki pengaruh yang signifikan dengan kemampuan komunikasi matematis siswa.

Adanya hubungan dan kontribusi kemampuan numerik terhadap kemampuan komunikasi matematis menunjukkan bahwa kemampuan numerik penting untuk dimiliki dan dikembangkan pada diri setiap siswa. Kemampuan numerik yang baik memudahkan seseorang dalam mengelola angka dan logika dengan aktivitas utama berpikir logis, melakukan perhitungan matematis, memecahkan masalah, dan menyusun pola-pola numerik serta hubungannya. Dengan kemampuan tersebut akan memudahkan seseorang untuk melakukan interpretasi berbagai ide matematis dalam bentuk simbol-simbol. Seseorang dengan kemampuan numerik tinggi memperlihatkan kecenderungan suka melakukan aktivitas berhitung dan memiliki kecepatan tinggi dalam menyelesaikan soal-soal atau masalah matematika (Irawan, 2016). Sedangkan Gunur et al., (2018) mengatakan sebagian besar materi yang ada dalam mata pelajaran matematika membutuhkan banyak sekali penghitungan dan membutuhkan kemampuan khusus yang dapat menunjang proses penyelesaiannya, oleh karena itu, dalam mempelajari matematika siswa dituntut untuk mempunyai kemampuan mengelola angka, melakukan perhitungan matematis dan memecahkan masalah.

Kusuma dan Budiyono (2014) mengemukakan bahwa pelajaran matematika akan lebih mudah dipelajari oleh orang-orang yang mempunyai kemampuan numerik yang tinggi. Hal ini didukung oleh pendapat Gunur et al., (2016) yang mengatakan bahwa kemampuan numerik merupakan dasar dalam belajar matematika, khususnya yang berhubungan dengan operasi hitung bilangan. Siswa akan mengalami kesulitan dalam belajar matematika apabila tidak mempunyai kemampuan numerik yang mencukupi (Achdiyat \& Utomo, 2018). Dengan demikian, kemampuan numerik yang berkembang dengan baik dalam diri siswa mampu membantunya dalam mengemukakan ide atau gagasan yang dimilikinya. Jayantika et al., (2013) menambahkan bahwa seseorang dengan kemampuan numerik mempunyai kemampuan mengelola logika dan angka dengan aktivitas utama berpikir logis, berhitung, menyusun pola hubungan serta memecahkan masalah

Selanjutnya, sesuai dengan hasil penelitian dan didukung oleh penelitian terdahulu, kemampuan spasial siswa penting untuk dikembangkan agar pembelajaran menjadi efektif. Kemampuan spasial adalah kemampuan seseorang untuk mengenali dan melakukan penggambaran atas objek atau pola yang diterima otak, dengan kata lain kemampuan spasial adalah kemampuan membaca gambar, bentuk ataupun pola. Menurut Ni'mah, Junaedi, dan Mariani (2017); Young, Levine, dan Mix (2018), kemampuan spasial merupakan kemampuan siswa dalam memahami perspektif ruang dan dimensi yang memiliki hubungan yang kuat dengan kemampuan matematis lainnya. Jika dicermati sebagian besar materi dalam pembelajaran matematika dapat disajikan dalam berbagai bentuk seperti gambar, tabel, diagram maupun pola-pola tertentu, bentuk-bentuk penyajian materi tersebut sangat berkaitan erat dengan kemampuan spasial seseorang. Menurut Febriana (2015) kemampuan spasial adalah kemampuan yang berhubungan dengan kemampuan mempresentasi, mentransformasi, dan mendeskripsikan informasi simbolis. Kemampuan spasial adalah kemampuan membaca gambar, bentuk atau pola-pola tertentu, sehingga seseorang dengan kemampuan spasial tinggi dapat dengan mudah memahami materi-materi tersebut. Hal ini didukung oleh Tambunan (2006); Vale dan Barbosa (2017) yang menyatakan bahwa adanya konseptualisasi spasial yang baik merupakan aset untuk memahami konsep-konsep matematika.

Selain penyajian materi dalam berbagai bentuk, adapun materi matematika yang menuntut siswa untuk berpikir secara abstrak, sehingga dalam pemahamannya siswa harus menggunakan imajinasinya. Kemampuan spasial yang berkembang dengan baik dalam diri siswa mampu membantu siswa dalam menyelesaikan soal-soal matematika yang berkaitan dengan menciptakan imajinasi bentuk dalam pikirannya maupun dalam wujud bendabenda tiga dimensi, atau membayangkan posisi suatu obyek geometri setelah obyek tersebut mengalami perputaran dan pencerminan serta menduga secara akurat bentuk sebenarnya dari bangun ruang geometri yang dipandang dari sudut pandang tertentu. Dengan kemampuan spasial yang berkembang dengan baik, siswa pun dipermudah dalam menyampaikan ide atau gagasan yang ada dalam pikirannya, dimana siswa mengalami kemudahan dalam menyatakan situasi nyata ke dalam gambar, tabel, atau diagram. 
Hasil penelitian juga menunjukkan bahwa kemampuan numerik dan spasial secara simultan berkorelasi dengan komunikasi matematis siswa. Dari temuan tersebut dapat disimpulkan bahwa jika seseorang memiliki kemampuan numerik yang tinggi dan disertai oleh kemampuan spasial yang tinggi pula, maka kemampuan komunikasi matematisnya juga akan tinggi. Dengan demikian, apabila siswa memiliki kemampuan mengelola angka dan logika dengan baik, serta didukung dengan kemampuan imajinasi atau membaca gambar juga baik, maka hal ini akan memudahkan siswa dalam mengekspresikan ide-ide matematika secara tertulis dengan menggunakan simbol matematis dalam menyelesaikan masalah. Dengan kata lain, semakin tinggi kemampuan seseorang dalam mengelola angka dan logika dengan aktivitas utama berpikir logis, melakukan perhitungan matematis, memecahkan masalah, serta mampu menyusun pola-pola numerik serta hubungannya dan didukung oleh kemampuan yang tinggi dalam mengimajinasikan perubahan-perubahan yang terjadi pada gambar setelah mengalami perputaran dan pencerminan, serta mampu menentukan persamaan dan perbedaan gambar, maka semakin tinggi pula kemampuan seseorang dalam menyatakan situasi nyata dan gambar secara tertulis ke dalam ide matematika, menggunakan istilah-istilah atau notasi-notasi matematika secara tertulis untuk menyatakan suatu ide, dan mengorganisasikan berbagai konsep untuk menyelesaikan masalah.

\section{SIMPULAN}

Berdasarkan hasil penelitian dan pembahasan, dapat disimpulkan beberapa hal. Pertama, terdapat hubungan yang signifikan antara kemampuan numerik dengan kemampuan komunikasi matematis siswa kelas VII SMPK Santu Fransiskus Xaverius Ruteng. Besarnya kontribusi kemampuan numerik terhadap kemampuan komunikasi matematis adalah $20,9 \%$. Hasil ini menunjukkan bahwa semakin baik kemampuan numerik seseorang maka semakin baik pula kemampuan komunikasi matematisnya. Kedua, terdapat hubungan yang signifikan antara kemampuan spasial dengan kemampuan komunikasi matematis siswa kelas VII SMPK Santu Fransiskus Xaverius Ruteng. Besarnya kontribusi kemampuan spasial terhadap kemampuan komunikasi matematis adalah $18,1 \%$. Hasil ini menunjukkan bahwa semakin baik kemampuan spasial seseorang maka semakin baik pula kemampuan komunikasi matematisnya. Ketiga, terdapat hubungan signifikan kemampuan numerik dan kemampuan spasial secara simultan terhadap kemampuan komunikasi matematis siswa kelas VII SMPK Santu Fransiskus Xaverius Ruteng. Besarnya kontribusi kemampuan numerik dan kemampuan spasial secara simultan terhadap kemampuan komunikasi matematis adalah 30,8\%. Dengan demikian, semakin baik kemampuan numerik seseorang yang didukung dengan kemampuan spasial yang baik, maka akan berdampak pada kemampuan komunikasi matematis yang baik pula. Kemampuan numerik dan kemampuan spasial secara simultan berpengaruh terhadap kemampuan komunikasi matematis siswa, sehingga kedua kemampuan tersebut perlu dimaksimalkan melalui aktivitas pembelajaran. Guru diharapkan mampu mendorong, mendukung, dan memberikan perhatian bagi siswa agar siswa memiliki kemampuan numerik yang baik dan kemampuan spasial yang baik.

\section{DAFTAR PUSTAKA}

Abed, E. R., Al-Absi, M. M., \& Abu shindi, Y. A. (2015). Developing a numerical ability test for students of education in Jordan: An application of item response theory. International Education Studies, 9(1), 161-174. doi: https://doi.org/10.5539/ies.v9n1p161

Achdiyat, M., \& Utomo, R. (2018). Kecerdasan visual-spasial, kemampuan numerik, dan prestasi belajar matematika. Formatif: Jurnal IImiah Pendidikan MIPA, 7(3), 234-245. doi: https://doi.org/10.30998/formatif.v7i3.2234

Badru, A. K. (2016). Problem-based instructional strategy and numerical ability as determinants of senior secondary achievement in mathematics. Journal of Education and Practice, 7(13), 89-95. Retrieved from https://www.iiste.org/Journals/index.php/JEP/article/view/30626

Carter, P. (2005). The complete book of intelligence tests: 500 exercises to improve, upgrade and enhance your mind strength. West Sussex, England: Wiley.

Delyana, H. (2014). Peningkatan kemampuan komunikasi matematis dan disposisi matematis siswa SMP melalui penerapan strategi the firing line dalam pembelajaran matematika (Unpublished magistes thesis). Universitas Pendidikan Indonesia, Bandung. 
Fatmasuci, F. W. (2017). Pengembangan perangkat pembelajaran berbasis masalah berorientasi pada kemampuan komunikasi dan prestasi belajar matematika siswa SMP. Jurnal Riset Pendidikan Matematika, 4(1), 32-42. doi: https://doi.org/10.21831/jrpm.v4i1.11325

Febriana, E. (2015). Profil kemampuan spasial siswa menengah pertama (SMP) dalam menyelesaikan masalah geometri dimensi tiga ditinjau dari kemampuan matematika. Jurnal Elemen, 1(1), 13-23. Retrieved from http://e-journal.hamzanwadi.ac.id/index.php/jel/article/view/78/66

Gunur, B., Makur, A. P., \& Ramda, A. H. (2018). Hubungan antara kemampuan numerik dengan kemampuan pemecahan masalah matematis siswa di pedesaan. MaPan: Jurnal Matematika dan Pembelajaran, 6(2), 148160. doi: https://doi.org/10.24252/mapan.2018v6n2a2

Gunur, B., Sariyasa, \& Ardana, I. M. (2016). Pengaruh pendidikan matematika realistik terhadap kemampuan pemecahan masalah matematika di tinjau dari kemampuan numerik siswa SMP Negeri 1 Cibal. Jurnal Pendidikan dan Pembelajaran Matematika Indonesia, 5(1). Retrieved from http://119.252.161.254/ejournal/index.php/JPM/article/view/2129

Habsah, F. (2017). Developing teaching material based on realistic mathematics and oriented to the mathematical reasoning and mathematical communication. Jurnal Riset Pendidikan Matematika, 4(1), 43-55. doi: https://doi.org/10.21831/jrpm.v4i1.10199

Harmony, J., \& Theis, R. (2012). Pengaruh kemampuan spasial terhadap hasil belajar matematika siswa kelas VII SMP Negeri 9 Kota Jambi. Edumatica: Jurnal Pendidikan Matematika, 2(1), 11-19. doi: https://doi.org/10.22437/edumatica.v2i01.598

Hartati, S., Abdullah, I., \& Haji, S. (2017). Pengaruh kemampuan pemahaman konsep, kemampuan komunikasi dan koneksi terhadap kemampuan pemecahan masalah. Jurnal Pendidikan Matematika, 11(2), 41-59 43-72. doi: https://doi.org/10.22342/jpm.11.2.3354.41-60

Irawan, A. (2016). Peranan kemampuan numerik dan verbal dalam berpikir kritis matematika pada tingkat sekolah menengah atas. AdMathEdu: Jurnal IImiah Pendidikan Matematika, IImu Matematika dan Matematika Terapan, 6(2), 121-130. doi: https://doi.org/10.12928/admathedu.v6i2.5443

Irawan, A., \& Kencanawaty, G. (2017). Peranan kemampuan verbal dan kemampuan numerik terhadap kemampuan berpikir kritis matematika. AKSIOMA: Journal of Mathematics Education, 5(2), 110-119. doi: https://doi.org/10.24127/ajpm.v5i2.669

Jayantika, N. T., Ardana, I. M., \& Sudiarta, P. (2013). Kontribusi bakat numerik, kecerdasan spasial, dan kecerdasan logis matematis terhadap prestasi belajar matematika siswa SD Negeri di Kabupaten Buleleng. Jurnal Jurusan Pendidikan Matematika Ganesha, 2(1), 1-12. doi: https://doi.org/10.23887/jppm.v2i2.981

Junita, R. (2016). Kemampuan representasi dan komunikasi matematis peserta didik SMA ditinjau dari prestasi belajar dan gaya kognitif. Pythagoras: Jurnal Pendidikan Matematika, 11(2), 193-206. doi: https://doi.org/10.21831/pg.v11i2.10655

Kemendikbud. (2018). Peraturan Menteri Pendidikan dan Kebudayaan Republik Indonesia Nomor 21 Tahun 2018 tentang Standar Isi Pendidikan Dasar dan Menengah. Retrieved from https://bsnp-indonesia.org/standar-isi/

Kusuma, V. D., \& Budiyono. (2014). Kemampuan verbal, numerik dan prestasi belajar matematika siswa SD di Kecamatan Ngemplak. Ekuivalen-Pendidikan Matematika, 13(3), 205-209. Retrieved from http://ejournal.umpwr.ac.id/index.php/ekuivalen/article/view/1851

NCTM. (2000). Principles standards and for school mathematics. Reston, VA: Author.

Ni'mah, L., Junaedi, I., \& Mariani, S. (2017). Mathematical literacy's vocational students based on logical and numerical reasoning. Infinity Journal, 6(2), 95-110. doi: https://doi.org/10.22460/infinity.v6i2.p95-110

Sukoco, H., \& Mahmudi, A. (2016). Pengaruh pendekatan brain-based learning terhadap kemampuan komunikasi matematis dan self-efficacy siswa SMA. Pythagoras: Jurnal Pendidikan Matematika, 11(1), 11-24. doi: https://doi.org/10.21831/pg.v11i1.9678 
Suparlan, A., \& Juhariah, J. (2009). Pengaruh minat dan kecerdasan numerik terhadap prestasi belajar matematika siswa. EduMa: Mathematics Education Learning and Teaching, 1(2), 129-137. Retrieved from https://edumajournal.wordpress.com/publikasi/volume-i-nomor-2/

Tambunan, S. M. (2006). Hubungan antara kemampuan spasial dengan prestasi belajar matematika. Makara Human Behavior Studies in Asia, 10(1), 27-32. doi: https://doi.org/10.7454/mssh.v10i1.13

Trafton, P. R., \& Midgett, C. (2000). Learning through problems: A powerful approach to teaching mathematics. Teaching Children Mathematics, 7(9), 532-536.

Vale, I., \& Barbosa, A. (2017). The importance of seeing in mathematics communication.Journal of the European Teacher Education Network, 12(7), 49-63. Retrieved from https://62.28.241.73/index.php/jeten/article/view/137

Whardani, F. (2016). Analisis kemampuan komunikasi matematis siswa kelas vii mts daarul hikmah pamulang pada materi segiempat dan segitiga (Skripsi sarjana tidak diterbitkan). Universitas Islam Negeri Syarif Hidayatullah, Jakarta.

Wibowo, D. C. (2016). Hubungan prestasi belajar matematika dengan kemampuan numerik dan inteligensi. Prosiding Seminar Nasional "Menjadi Guru Inspirator" Prodi PGSD FKIP-Univesitas Muhammadiyah Purwokerto (pp. 29-36).

Wijayanto, A. D., Fajriah, S. N., \& Anita, I. W. (2018). Analisis kemampuan komunikasi matematis siswa SMP pada materi segitiga dan segiempat. Jurnal Cendekia: Jurnal Pendidikan Matematika, 2(1), 97-104. doi: https://doi.org/10.31004/cendekia.v2i1.36

Yamane, T. (1967). Statistics: An introductory analysis (2nd ed.). New York, NY: Harper and Row.

Young, C. J., Levine, S. C., \& Mix, K. S. (2018). The connection between spatial and mathematical ability across development. Frontiers in Psychology, 9, 1-7.doi: https://doi.org/10.3389/fpsyg.2018.00755 